\title{
The Impact of Symbolism on Some British and American Modernist Writers
}

\author{
Dalila Karakaçi \\ PhD. Candidate, \\ University "Aleksander Moisiu", Durres, Albania \\ E-mail:karakacidalila@yahoo.com
}

\section{Doi:10.5901/mjss.2014.v5n1p565}

\begin{abstract}
This paper will be focused on the impact of symbolism on some British and American modernist writers. Through an analysis of the main characteristics of symbolism and modernism, I will arrive to point the level of impact of one literary movement over the other. Symbolism initiated as a drive to portray a different actuality from that of naturalism and realism, producing an impact on modernist literature by moving the focus of narration on word arrangement and images. Being the first symbolist novel, Huysmans's A Rebour shows artistry in the usage of language. On the other hand, Dujardin's Les Lauriers sont coupes technique disregarding the cause- effect plot and converging on the gathering of images and symbolic means would be used intensively by Henry James and after WWI writers. The technique of intersecting time, space and disorder of information transmitted through the senses is widely exploited by Mallarme, Rimbaud, Valery and Baudelaire. The impact of Proust on Joyce is touchable not only in the importance given to the connection amid art and life, through the biome of personages and time used in the novel, but also in the significance prearranged by the language to transmit the form of the novel. The personages of Faulkner and Wolf are identified through images, symbols and language used since they subsist only in relation to these symbols and words communication, resulting to be significant forms of modernist technique. What integrates these two literary movements goes further to the usage of joint techniques of expression and is focused on the same ambition of making art, leaving apart affects, taking into consideration its intricacies and impossibilities.
\end{abstract}

Keywords: Symbolism, Modernism, images, language, interior monologue

\section{Introduction}

Symbolism was an artistic movement that started to flourish by the end of the XIX century in poetry, prose and other arts too. The foundation of symbolism is found in the rebellion of some French poets as: Stephan Mallarme, Paul Verlaine, Arthur Rimbaud and Jules Laforgue hostile to strict techniques and subject matters in conventional poetry in France. This movement extended in Russia, Belgium and later in other countries too. In literature, its aesthetic owns to Paul Verlaine and Stephan Mallarme, while its style owns to Charles Baudelaire. It initiated as a drive to portray a different actuality from that of naturalism and realism. Whereas naturalism propound reality in details, directing to the ordinary, symbolism on the other hand, aspired imagination, dreams, and truths unfolded indirectly. Inspiration for their outline came from sensations, psyche and dreams, presenting the instantaneous feelings that disturbed the inner self and understanding of man of their age. Reality, in symbolist technique, is displayed through a symbolic meaning or a symbolic character. While it was conjuring to the world the concepts of symbolism in his manifesto, Jean Moro (1886) verbalized that, "In this art, scenes from nature, human activities, and all other real world phenomena will not be described for their own sake; here, they are perceptible surfaces created to represent their esoteric affinities with the primordial ideas."

The Symbolist poets were inspired by hermeticism and some elements of Parnassian's, as musicality within the poetry and recreation with words. Free verse was the principal technique of Symbolist poets, with the challenge of inducing or showing things through figures that symbolize the noteworthy mental and emotional condition of the poet. Contrary to Romantic poets, who exploited exceptional objects, the Symbolist put a symbolic connotation on everything showing to be more intense. In prose, Joris-Karl Huysmans and Paul Adam were the most illustrative writers, but prose shows to be less experimenting than poetry. Its narrative techniques conjure particular condition of the mind producing a static style of acting. The Symbolist maintained the notion of "Art for Art's Sake", keeping away from external determination and focusing on the beauty of the poem itself. Symbolist artists and Schopenhauer considered art as a shelter from the devastating force of the will on the world they lived. 


\section{The Symbolist Novel}

A characteristic of Symbolist novel is the usage of "expanding symbols" (E.K. Brown, 1950). The search for a symbolic technique dates back in some novels of the 1880s. In 1884, J.K. Huysmans distributed his novel A Rebours (Against Nature).In this book, the author narrates the symbolist experience together with the eccentric personage, relinquishing naturalism. The omniscient narrator interferes in every moment to facilitate the reader in the understanding of the events and the writer in the evolvement of the events. The main character, Des Esseintes, forgoes living in a mediocre world, isolating himself from such world. Huysmans utilizes a selected language to transmit this experience. Above all, this work shows an artistry in the usage of language, where the author traps himself in a thriving oratory and articulation, perhaps in his subconscious, to the understanding of symbolism.

The novel of another Symbolist author, Dujardin, Les Lauriers sont coupes (We'll to the Woods no More, 1887), changes from that of Huysmans. The author is embedded in the mind of the main personage and flourishes his ideas within a short period of time, six hours, in an April Paris evening. The meeting with his girlfriend absorbs the primary position in his meditations. In this novel there is not so much external plot because the action is displaced within the feelings of the main personage, analyzing his reflections, expressed through a long interior monologue. The time of the action within the novel moves from a happy past to a craving future. Even though Daniel Prince's life is not isolated from human contact, likewise Des Esseintes, he is a typical symbolist personage, like Laforgue's Hamlet or Mallarme's Herodiade or Des Esseintes that suffers from the indecision and frustration of life. Dujardin applies the technique of interior monologue to express the meditations of his hero. This device will be a key method of expression and narration by the modernist writers. The internal action of the novel, introduced through disturbing figures, continuing recurrence to time and place and interior monologue of the hero demonstrates a withering away of the external plot. The novelty introduced by Dujardin in the novel narration technique, disregarding the cause- effect plot but converging on the gathering of images and symbolic means, would be used intensively by Henry James and after WWI writers.

\section{Some Characteristics of the Modern Novel}

Modernist novel was affected by French Symbolism. Elements of a symbolist bequest are reflected in the work of Proust, Joyce, Conrad, Wolf and Faulkner. While analyzing modernism, Elizabeth Bowen (1962) defines that "We want the naturalistic surface, but with a kind of internal burning." (p.268) In her argumentation, Bowen was striving to exert a pull on the exploration of innovative techniques, left apart, modernism could have no implication. This movement of thought is characterized by the immediate entrance of the reader into the inner life of the personage having no access to comments and interpretations from the writer and exposing the personage most secret ideas, which are part of his/her unconsciousness. Therefore, the concern of the writer is transposed within the personage. Such technique enables a divulgence of the personage inner self, in particular, and human world insight, in general.

This is a delving into the process by which the mind venture the reality, adjoining the reality, presented through streams of ideas not organized coherently, but related through association, oppression and alienation. The innovative inside of consideration in literature needed innovative techniques of narration, to reproduce the latest developments of the time. Modernist writers started the narration from within the character and illustrated outside events only if they impose, initiating a lot of associations in the conscience of the personages. It is avoided the sequential narration, the exposition, climax, catastrophe and conclusion; even the vertical presentation of a personage. The reader is placed at the center of the story because he will arrange the events on his own to give meaning. He has to draw his conclusions because the focal point of the writer is more on the showing that telling, by disintegrating narration, breaking up events into lumps of time linked through recurrent images and symbols. The author is absent.

\section{The Impact of Symbolism on Modernist Writers}

Symbolism movement had an impact on modernist literature by moving the focus of narration on word arrangement and images. While analyzing this influence on modernist writers as Yeats, Joyce, Elliot, Stein, Valery and Proust, Edmund Wilson notes that "Symbolism represented a daydreaming retreat into things that are dying -the whole belle-lettristic tradition of Renaissance culture perhaps, compelled to specialize more and more, more and more driven in on itself, as industrialization and demographic education have come press it closer and closer" (Wilson, 2004, p.73). A novelist fully influenced by French Symbolism was James Joyce. A novel, at the heart of modernist experience, is Ulysses (1922).Indubitable; Ulysses would later influence other writers of his age, and afterwards, in the usage of techniques. In 
Ulysses it is widely seen a resemblance between Dujardin and other French Symbolist. Stephan Dedalus and Des Esseintes have the same exotic feeling for French manuscripts of overdue nineteen century, while Leopold Bloom and Daniel Prince accompany themselves with musical under song reflecting their emotional state and motto of life.

Like Leopold Bloom, even Daniel prince, is chased by the same hopes and memories of the past and present together unrewarded sexual necessitates. Both of them undergo frustrated intimate relations, causing to throw themselves in the exotic sexual hinterlands of pubs, in the case of Bloom, and 'Cafe Oriental, restaurant', in the case of Daniel Prince. The emotional divagations of these two men are the same, even though within different contexts; Bloom's movement is during the night while Daniel Prince's during the day. The technique of intersecting time, space and disorder of information transmitted through the senses is widely exploited by Mallarme, Rimbaud, Valery and Baudelaire. The impact of Proust on Joyce is touchable not only in the importance given to the connection amid art and life, through the biome of personages and time used in the novel, but also in the significance prearranged by the language to transmit the form of the novel. Under the influence of Symbolists, Joyce, presents musical elements in Ulysses as a motive of their musical sensibility, pointing "to e prime aspect of its form" (Ellmann, 1972, p.103) Proust applies the overture of Wagner in his writing; Joyce applies sounds that resemble that of a fugue.

An amazing number of authors, draw on symbols and images reflecting an immediate impact of symbolists on modernist writers. As I Lay Dying (1930), of William Faulkner, is centered on the burial procession of a woman in a rustic Mississippi. The whole story is focused on the internal monologue of the family members and the departed woman too. Meditations on life, death, drift and paralytic situation of the people while walking in the procession compose the content of the novel. The Waves (1931) of Virginia Wolf, narrates the physical growth and maturity of six different personages. Both authors employ the interior monologue to impenetrate in the conscious of the personages. The reader is not prearranged for the actions happening, he is left without stage direction, since is removed the external plot and he is set in the center of a continuing information. Before entering the consciousness of a personage, Faulkner bold types his name, as a suggestion for the monologue of whom we are reading. Faulkner bold types the name of Darl (Faulkner, 1930, p.50) to admonish entering in his mind and consciousness. Wolf uses the expression "said Jinny" (Wolf, 1931, p.30) to sign the passing from the consciousness of one personage to another. Even supposing different, the effect these techniques have on the reader is the same.

The personages are identified through images, symbols and language used since they subsist only in relation to these symbols and words communication, resulting to be significant forms of modernist technique. Faulkner attaches an identifying symbol to every member of the Bundren family to follow the maturation and change of consciousness of every individual in this family; Cash is identified with a coffin, Vardaman with a fish and Jewel with a horse. Wolf typifies her personages through returning sentences and poetic symbols. Louis is typified through the chained beast stamping on the shore, while the appearance of Neville in the novel is accompanied by the phrase "The wild hunting song, Percival's music" (p.176). Jewel is the only personage that speaks less; therefore his ideas are conveyed through e small monologue. While reading Vandam, the reader notices a repeated phrase "My mother is a fish" (Faulkner, p.73). This hitching disturbs his ideas expressed through a non communicative language that transmits his turbulent state of mind. Cash, a carpenter, communicates through the language of carpentry.

Addie has one monologue in the novel, but the whole story is related to her death procession. In that monologue, she estimates the frivolity of words to communicate ideas and feelings as "just a shape to fill a lack..." (p.245). The same frivolity of language is evident in the personage of Darl, turned slowly into lunatic by the over analyses of language significance, but he gives the impression of predicting the fascinations hunting of his family members and overlooks the center of narration. The same overlooking and thinking is seen in the other personage of The Waves, Bernard. The personages of Faulkner and Wolf are disturbed by this usage of language. Neville says, "Not the words- but what are the words?.. I shall be clinger to the outsides of words all my life." (p.234) The dying Percival and Edi are used to give form to the structure of the novel, even though Percival exist only in the minds of the personages within the novel. The peculiarities in the way the personages express themselves, result from disillusionment in the functions of the language, but even express the tormented psychological conditions of these people.

A courageous language of narration is used in the other novel of Faulkner, The Sound and the Fury (1929), in the course of which, he transmits the whole dense psychological atmosphere of the characters. It is a language that permits the author to communicate the failure of this family to adjust to the modern world. The most experimenting part is that of Benjy. Benjy is unable to communicate because of his mental deficiency. He arrives to converse only through his responses to stimuli which are sensory and never rational. The smell is a device ameliorating him to transmit the reaction against the surroundings and to communicate indirectly with the entire world and his family in particular, "I couldn't feel the gate at all, but I could smell the bright cold" (Faulkner, p.11). His perceptions, in his interior monologues, are clearly 
given while illustrating his everyday life and inferring conclusions about his family relations. Whenever his sister's name is mentioned he links her to the smell of her perfume, serving as an identifying symbol, or even his father's death is identified with the smell of the death. Consequently, the language Benjy employs to converse is irrational, disordered, non communicative, eruption of form, syntax and grammatical rules. Its difficulty in understanding stays because of generating a dreamlike atmosphere.

At the same level of abstraction is even Quentin's episode, Benjy's brother. Although he is not of the same intensity of intellect as Benny, the amount of intricacy reading him is the same. From the beginning to the end of his part, he starts becoming fanatical with parts from memory, remarkably related to his sister Caddy and her experience with men. He becomes fanatical with the time. Past memories become an obsession taking the form of a violent flowing stream, "and i you dont believe i am serious and he i think you are too serious to give me any cause for alarm you wouldnt have felt driven to the expedient of telling me you had." (p.56) Sometimes, Quentin sounds like Benjy when the smell of flowers renders him to particular moments with Caddy. He blends time, concepts and images resulting in a confusion of ideas and syntactic structures, producing the identical dreamlike atmosphere, similar to the monologues of Benjy.

In the Sound and the Fury, Faulkner extensively obsesses his personages with symbolic images referring to time, and clocks, in particular. All the personages mention the usage of the clock, but differently linked to dissimilar experiences. Quentin is one of the characters that lived trapped in the memories of the past. He detests clocks, because they primarily keep traces of the moments passing, exceptionally those instants of the past and present. For him, clocks indicate that time is a living organism, that changes constantly and if lost, people lose chances to remedy state of affairs. It is hopeless living in a static time as Quentin craves. Only by stopping the clocks, stopping to mark the past, can he regulate Caddy's life.

Alike indication is even captured in his relation to personal watches, which are used to indicate personal time. On the contrary, clocks are more applied to mark the public time. Quentin does not intend to impede the public time but every element that illustrates his private time. The watch given by his father is a mean to make him conscious constantly of the personal time, "It was Grandfather's and when Father gave it to me he said I give you the mausoleum of all hope and desire." (p.64) The rejection of his family watch symbolizes the non tracking of his individual experiences, which are all caught up in the past as agent of obsolete conventions in Southern American society. At this point, it is quite understandable his desire to break the watch as a symbol of smashing his relation to time and life. Time being life, he intersects his bond to life.

\section{Conclusion}

James, Faulkner, Wolf, Joyce, Proust, Conrad and other modernist writers have in their writings influences of the Symbolists, being their inheritors, though surpassing the concern of Symbolist. They reflect an evolution in the techniques of narration and the idea of making art. Their image of literature goes further that of a documentary, intently turning into a lyrical one. These writers started the narration from within the character and illustrated outside events only if they impose, initiating a lot of associations in the conscience of the personages, disregarding the cause- effect plot but converging on the gathering of images and symbolic means It is avoided the sequential narration, the exposition, climax, catastrophe and conclusion; even the vertical presentation of a personage. What integrates these two literary movements goes further to the usage of joint techniques of expression and is focused on the same ambition of making art, leaving apart affects, taking into consideration its intricacies and impossibilities.

\section{References}

Brooker, Joseph. (2004).Joyce's Critics: Transition in Reading and Culture. Madison, Wisc: University of Wisconsin Press.

Brown, E.K. (1950). Rhythm in the Novel. Toronto.

Ellmann, Richard. (1972).Ulysses on the Liffey. London.

Faulkner, William. (1991).As I lay Dying. New York: Vintage, Trade Paper Back edition.

Faulkner, William. (1990).The Sound and the Fury. New York: Vintage International.

Moro, Jean. (1886). "Le Symbolisme". In Le Figaro. (Online) Available:

http://en.wikipedia.org/wiki/Symbolism_(arts) (November 9, 2013)

Scholes, Robert. (Ed.). (1962).Approaches to the Novel, Materials for a Poetic. San Francisco: Chandler Publishing Company.

Wolf, Virginia. (1931).The Waves.New York: Harcourt, Brace, Jovanovitch. 